\title{
First-year at university: The effect of academic employability skills and physical quality of life on students' well-being
}

\author{
Michèle Baumann*, Marie-Emmanuelle Amara, Senad Karavdic and Arthur Limbach-Reich \\ Research Unit INSIDE, University of Luxembourg, Walferdange, Luxembourg
}

Received 18 December 2012

Accepted 6 May 2013

\begin{abstract}
.
BACKGROUND: With increasing access at European universities, supporting and promoting the high education, students' mental well-being and generic employability capacities have become priorities, but their respective influences, after an adaptation period of seven months, remain unclear.

OBJECTIVE: Our aims were to analyse the relationships between students' well-being and self-perceived academic employability skills, and other social and environmental factors.

METHODS: Three hundred and twenty-one freshmen students at the end of their first year completed an online questionnaire. Two instruments were used to assess well-being: the General Health Questionnaire (GHQ-12), which explores psychological suffering, and the psychological quality of life subdomain of the Whoqol-bref.

RESULTS: Psychological Whoqol-bref scores are linked to the academic employability skills (AES) items of drafting, critical spirit, problem-solving, teamwork, and supervision/direction of others, and has positive effects on AES score and on the following Whoqol-bref domains: physical, social relationships and environmental. Although three of six psychological Whoqol-bref items (ability to concentrate, satisfaction with self, negative feelings) are correlated with GHQ-12 items (sleeping, decisionmaking, feeling under strain, problem-solving, depression, self-confidence, thinking about self, feeling happy). GHQ-12 score is negatively linked with Whoqol-bref physical.

CONCLUSIONS: For better quality of life, and improved employability skills, innovative activities should be developed to ascertain the sustainable academic's abilities of students.
\end{abstract}

Keywords: Psychological Whoqol-bref, psychological suffering, GHQ-12, freshmen students, mental well-being, academic employability skills

\section{Introduction}

Among young Europeans, psychological disorders including depression represent a growing public health issue. This is particularly true of students, who are more and more susceptible to depressive mood and

*Corresponding author: Prof. Michèle Baumann, Research Unit INSIDE, University of Luxembourg, L7201 Walferdange, GrandDuchy of Luxembourg, Luxembourg. E-mail: michele.baumann@ uni.lu. anxiety as universities become increasingly competitive in attempts to meet occupational requirements under demanding conditions [1-5]. With increasing access at European universities, supporting and promoting the high education, students are more likely to confront difficulties that can be attributed to an imbalance between learning conditions and the capacity of students to deal with them, given their socioeconomic and cultural contexts [6]. The social and academic circumstances they face expose them to a number of socio-economic, environmental, and psy- 
chological factors that may result in alterations in social and mental health $[7,8]$ with an impact on academic achievement [9]. Despite many disorders among this population, be they somatic (tiredness, headaches, backaches), psychological (depression, suicidal ideation/attempts) or behavioural and other (eating habits, substance abuse), very few studies have been dedicated to student health $[6,10,11]$.

The past decade has seen a rapid expansion in the number of students in tertiary education [12] and the general focus on obtaining skills in order to gain good employment has led to a plethora of graduates and to a larger number of applicants for any given job. At the same time, too many students drop out and leave university without a diploma as a result of long-lasting lack of learning motivation, failure to meet expectations and loss of confidence in the institution's project, especially as first-year undergraduates [13]. However, social and occupational status in adulthood and health status throughout life are determined by success in education and by the number of years of schooling [14]. This finding enabled us to identify some challenges and difficulties related to transition periods. These issues may have greater impact among adolescents from families with lower education, lower socio-economic status, and fewer resources [6]. In this context, many students face considerable difficulties in the transition from family home to dormitory and the shift between different circles of companions and social networks [15], which sometimes lead to dropping out. The first year of student life is a vulnerable period in which young people establish and adjust new psychological identities [16]. At the beginning of the academic year, students may reorganise their daily lives differently. If they go home each evening to their families, they must negotiate their new social activities with their parents. This is common among students native to Luxembourg - one of the smallest countries in Europe $\left(2600 \mathrm{~km}^{2}\right.$ with a maximum distance of $\left.82 \mathrm{~km}\right)$. In contrast, students who live away from home and family must adjust their behaviour in accord with a new environment that can present various difficulties (such as social isolation, unhealthy eating habits, long commuting times). Both situations may impact on family relationships and personal identity. For this reason, in our study we evaluated the health status of students in the first and the last months of the first academic year.

The sustainable employability of graduates - i.e. their capability to gain initial employment, maintain employment, and obtain new employment if required [17] - is a priority for European universities.
Thus, perceptions of the purpose and process of higher education have varied over time and now employability is understood less as a generic quality that can be achieved whatever the academic level but more as a product of higher education. For policy makers, to be a graduate is not sufficient for a highly competitive and flexible job market. Numerous students looking for work also believe that a diploma is not sufficient to secure employment; they think they must have the qualities and the capabilities required for enterprise in order to be competitive in the job market $[18,19]$. Today, students must, during their courses, not only acquire the knowledge necessary to obtain the diploma they are preparing for, but also acquire the competences sought by employers [20]. They are encouraged to self-learn, self-actualise and self-initiate. In other words, students need active career planning at university; they have to be led to self-management, i.e. to thinking about their own career objectives and how to achieve them. Recently, effort has been put in to determining what capabilities are most relevant to employability. Several lists of skills have been conceived by professionals and teachers. They include problem-solving, communication, teamwork, information technology, and selfmanagement. According to this, becoming employable appears to represent a new challenge, the responsibility for which depends on individual capabilities, thus creating considerable pressure on the student's life [19, 21].

Well-being is considered to be an outcome of quality of life; indeed there is a cognitive connection between an individual's aspirations and achievement [22]. Wellbeing is essential for effective learning, and a good school education is a strong predictor of lifelong psychological health and quality of life in different kinds of populations, settings and times. Also, well-being does not necessarily refer to fulfilment in all aspects of life and may differ from objective appraisals made by others.

Thus, as well as improving students' employability skills, there is a real need for universities to pay attention to their mental health. Two tools which assess the general well-being state of students are often used to explore psychological suffering or psychological quality of life (see Table 6). We opted to include both in our survey. However, no study was identified in which these instruments were used to look at relationships between indicators of academic achievement (actual module mark; performance or employability skills; perceived importance of achieving grades). Despite this, these tools are related to past research and 
their relevance to health concepts, policy and guidelines for implementation is firmly established. The first is the psychological domain of the brief World Health Organisation Quality of Life (Whoqol-bref) [23] scale, a widely-used tool that is validated among university students [24-27]. The second instrument is the short-version of the General Health Questionnaire [28, 29], which screens for psychological suffering. Its psychometric properties have been thoroughly validated. The evidence confirming the validity of this instrument among university students is generally strong [8, 30,31]. Both instruments are used internationally and have been validated in different languages. Because their widespread use is recommended by the European framework [20], many data are available for international comparisons.

Actually, the links between health and self-perceived skills for employability [32] are still not really understood. In a context where universities are expected to promote student satisfaction, well-being and employability, to provide support to those looking for employment and to develop a participatory process [20], our research questions are: For first-year university students, are well-being and high academic employability associated? What demographic, social and environmental determinants affect internal mechanisms of psychological suffering or quality of life and of academic skills for employability?

First-year students in university should be appropriately monitored because of the need to identify any problems with well-being and academic competence as quickly as possible. First-year students are also of most interest as they face the changes associated with a new lifestyle, and are young and discovering university life; their new experiences are likely to lead to the emergence of interesting issues to investigate. By launching an action plan at the beginning of university life, we aim to reduce disparities in skills acquired during prior education. Focusing on the period between the seventh and ninth months after the beginning of the courses, the main aim of our study is to analyse the relationships between well-being (psychological suffering and quality of life), and employability skills including other determinants (environmental and social relationships, quality of life, satisfaction with university services, socio-demographic characteristics). The secondary aim is to explore what is the most appropriate psychological instrument with which to evaluate student mental well-being.

\section{Materials and methods}

\subsection{Participants and procedure}

Between seven and nine months after the start of their first year at university, 973 students from Sciences and Technology, Law and Finances and Social Sciences at the University of Luxembourg were invited to participate in a cross-sectional study.

Our study protocol was approved by The Ethical Research Committee of the University, which approved an online instrument as appropriate for "asking students to fill in the survey during courses". Delegates from students' associations and a member of the research team provided information about the goals of the survey and all respondents gave informed consent for participation.

During a class, the research team (with co-operation of delegates from students' associations) presented the study and its aims, and students were assured that nonparticipation in this survey would not have an effect on academic assessment. Flyers, posters, electronic displays in halls and cafeteria, and e-mails to all students were used for the three reminders. Students were contacted via their academic e-mail and asked to complete, anonymously, a self-reported questionnaire in the language of their choice (French, German or English).

\subsection{Measures}

\subsubsection{Two instruments described each student's well-being}

- The Whoqol-bref psychological domain (subscale 6 items) measured on a five-point scale (Cronbach's alpha 0.77). The higher the score, the better the psychological quality of life. It has been validated in the languages used for the investigation: German [33], French [34] and English [23].

- The General Health Questionnaire (GHQ-12 items) was scored on a four-point scale (range 0-36) (Cronbach's alpha 0.75). The lower the score, the lower the psychological suffering. The GHQ-12 is in English [35], German [36], and French [37].

\subsubsection{One explored the student's academic employability skills}

- The Academic Employability Skills (AES) scale is a self-assessment tool measuring capacity in drafting, problem-solving, teamwork, supervision /direction of others, and use of new technolo- 
Table 1

Socio-demographic characteristics between non-responders and responders. \% or mean (SD)

\begin{tabular}{|c|c|c|c|}
\hline & Non-respondents & Sample & $p$-value \\
\hline \multicolumn{4}{|l|}{ Faculties } \\
\hline Sciences and Technology (ST) & 27.5 & 29.0 & \multirow{3}{*}{0.740} \\
\hline Law and Finance (LF) & 38.3 & 39.3 & \\
\hline Social Sciences (SS) & 34.2 & 31.8 & \\
\hline Age: mean (SD) & $20.6(3.2)$ & $21.0(4.0)$ & \multirow[t]{2}{*}{0.091} \\
\hline$[\min ; \max ]$ & {$[18 ; 44]$} & {$[17 ; 57]$} & \\
\hline \multicolumn{3}{|l|}{ Sex } & \multirow[t]{3}{*}{$<0.001^{* * *}$} \\
\hline Male & 53.7 & 42.7 & \\
\hline Female & 46.3 & 57.3 & \\
\hline \multicolumn{4}{|l|}{ Nationality } \\
\hline Luxembourger & 62.4 & 63.9 & \multirow[t]{2}{*}{0.662} \\
\hline Other & 37.6 & 36.1 & \\
\hline Grant aided students & 4.8 & 2.8 & 0.150 \\
\hline Handicapped students & 0.2 & 0.6 & 0.214 \\
\hline \multicolumn{4}{|l|}{ Type of course } \\
\hline Full-time & 98.6 & 98.4 & \multirow[b]{2}{*}{0.716} \\
\hline Part-time & 1.4 & 1.6 & \\
\hline \multicolumn{4}{|l|}{ 12th grade diploma } \\
\hline General & 67.6 & 70.7 & \multirow[t]{2}{*}{0.330} \\
\hline Technical/Professional & 32.4 & 29.3 & \\
\hline \multicolumn{4}{|l|}{ Type of lodging } \\
\hline With family & 91.3 & 90.7 & \multirow{3}{*}{0.351} \\
\hline University hall & 1.5 & 0.6 & \\
\hline Other & 7.2 & 8.7 & \\
\hline
\end{tabular}

${ }^{*} p<0.05,{ }^{* *} p<0.01,{ }^{* * *} p<0.001$.

gies. The level of each was estimated on a fourpoint scale from 'not very good' to 'excellent' (Cronbach's alpha 0.76). English and French versions were available [38]; the German version was translated and back-translated by experts.

\subsubsection{Other factors}

- Satisfaction with university services included six items scored in a range from 'very dissatisfied' to 'very satisfied'.

- Three other Whoqol-bref domains were assessed on five-point scales. The Cronbach's alpha internal is 0.77 for physical (7 items) and environmental ( 8 items), and 0.64 for social relationships (3 items). Subscales have been validated in the languages used for the investigation: German [33] French [34] and English [23]. The higher the score, the better the quality of life.

- Socio-demographic characteristics: sex, age, nationality, 12th grade diploma, level of education of the parents and their professional status.

\subsection{Analysis of data}

We performed a regression of each dependent variable of the well-being: the psychological Whoqol-bref
(6 items) score and the General Health Questionnaire (GHQ-12 items) score. Among potential explanatory variables, we selected those with a significant simple effect and/or significant interaction with the two wellbeing scales at the $p<0.10$ level, after which we proceeded with a multiple regression.

\section{Results}

Between seven and nine months after the beginning of their first year at university, 321 students (mean age, 21 years) filled out the online questionnaire. Women predominated among participants $(57.3 \%$ vs. $46.3 \%$ among non-respondents, $p<0.001$ ); see Table 1 .

Female students were more represented in Social Sciences $(77.5 \%)$ than in Law and Finance $(52.4 \%)$ and Sciences and Technology (41.9\%). Natives of Luxembourg were also more represented in Social Sciences $(80.4 \%$ vs. $47.6 \%$ in Law and Finance). Satisfaction with university services was highest among Law and Finance students (mean 69.9/100 vs. 63.4 in Sciences and Technology). Social Sciences students achieved the best Academic Employability Skills (AES) scores (mean 76.1/100 vs. 74.9 from Sciences 
Table 2

Social and demographic characteristics, and other factors: \% or mean (SD)

\begin{tabular}{|c|c|c|c|c|c|c|}
\hline & & $\begin{array}{c}\text { Total sample } \\
N=321\end{array}$ & $\begin{array}{l}\text { Sciences and technology } \\
\qquad N=93\end{array}$ & $\begin{array}{l}\text { Law and finance } \\
\qquad N=126\end{array}$ & $\begin{array}{l}\text { Social sciences } \\
\qquad N=102\end{array}$ & $p$-value \\
\hline \multicolumn{3}{|l|}{ Group } & 29.0 & 39.3 & 31.8 & \\
\hline Sex & Female (vs. male) & 57.3 & 41.9 & 52.4 & 77.5 & $<0.001^{* * *}$ \\
\hline Nationality & Luxembourger & 63.9 & 67.7 & 47.6 & 80.4 & $<0.001^{* * *}$ \\
\hline $12^{\text {th }}$ grade diploma & General & 70.7 & 66.7 & 67.5 & 78.4 & 0.116 \\
\hline Father's education level & Under $12^{\text {th }}$ grade & 64.2 & 56.5 & 65.8 & 69.1 & 0.188 \\
\hline Mother's education level & Under $12^{\text {th }}$ grade & 69.2 & 65.9 & 68.4 & 73.2 & 0.548 \\
\hline Father's professional status & Manual worker & 66.0 & 58.1 & 66.7 & 72.2 & 0.133 \\
\hline Mother's professional status & Manual worker & 79.3 & 77.6 & 77.8 & 82.5 & 0.637 \\
\hline \multicolumn{2}{|l|}{ Age (year) } & $21.0(4.0)$ & $20.8(4.3)$ & $20.9(3.5)$ & $21.4(4.2)$ & 0.561 \\
\hline \multicolumn{2}{|l|}{ GHQ-12 score } & $12.4(4.4)$ & $13.9(4.6)$ & $11.7(5.0)$ & $12.4(3.6)$ & 0.221 \\
\hline \multicolumn{2}{|l|}{ Psychological Whoqol-bref } & $73.6(14.4)$ & $72.0(14.7)$ & $74.1(14.3)$ & $74.6(14.3)$ & 0.424 \\
\hline \multicolumn{2}{|l|}{ Physical Whoqol-bref } & $72.9(14.9)$ & $65.7(14.8)$ & $73.4(14.6)$ & $75.8(14.6)$ & 0.058 \\
\hline \multicolumn{2}{|c|}{ Social relationships Whoqol-bref } & $74.0(18.3)$ & $73.2(17.0)$ & $72.2(17.4)$ & $77.0(20.2)$ & 0.140 \\
\hline \multicolumn{2}{|c|}{ Environment Whoqol-bref } & $74.0(13.8)$ & $74.2(12.9)$ & $74.1(13.8)$ & $73.7(14.8)$ & 0.983 \\
\hline \multicolumn{2}{|c|}{ Satisfaction with university services } & $66.9(9.6)$ & $63.4(11.2)$ & $69.9(10.1)$ & $65.3(7.4)$ & $0.020^{*}$ \\
\hline \multicolumn{2}{|c|}{ Academic Employability Skills (AES) score } & $72.7(13.0)$ & $74.9(11.7)$ & $68.2(13.5)$ & $76.1(12.1)$ & $<0.001^{* * *}$ \\
\hline \multicolumn{2}{|c|}{ AES item 1-Drafting/writing } & $75.7(18.1)$ & $76.2(17.6)$ & $71.5(19.3)$ & $80.3(15.8)$ & $<0.001^{* * *}$ \\
\hline \multicolumn{2}{|c|}{ AES 2 - Critical spirit/having sound judgment } & $72.2(17.1)$ & $71.4(17.0)$ & $69.0(17.7)$ & $77.0(15.3)$ & $0.002^{* *}$ \\
\hline \multicolumn{2}{|c|}{ AES $3-$ Problem solving } & $73.4(17.5)$ & $77.7(16.8)$ & $69.1(17.9)$ & $74.9(16.5)$ & $<0.001^{* * *}$ \\
\hline \multicolumn{2}{|c|}{ AES 4-Teamworking } & $75.9(19.8)$ & $77.7(19.9)$ & $69.3(18.7)$ & $82.5(18.6)$ & $<0.001^{* * *}$ \\
\hline \multicolumn{2}{|c|}{ AES 5 - Supervision/direction of others } & $66.4(20.4)$ & $67.6(19.7)$ & $62.9(21.0)$ & $69.6(19.9)$ & $0.037^{*}$ \\
\hline \multicolumn{2}{|c|}{ AES 6-Use of new technologies } & $72.4(20.1)$ & $78.6(16.7)$ & $67.5(20.5)$ & $72.7(21.0)$ & $<0.001^{* * *}$ \\
\hline
\end{tabular}

${ }^{*} p<0.05,{ }^{* *} p<0.01,{ }^{* * *} p<0.001$.

and Technology vs. 68.2 from Law and Finance); they mainly declared capacities for drafting/writing, critical thinking, decision-making and team working; see Table 2 .

No correlation was found between socio-demographic characteristics and the psychological Whoqolbref or GHQ-12 scores. However, both scores were linked with Whoqol-bref physical $(0.64$ and -0.36 , respectively), social relationships $(0.51$ and -0.20$)$ and environmental (0.51 and -0.26) domains. Psychological Whoqol-bref score is positively associated with the AES ( $r$ 0.25, $p<0.001)$; this relation is verified for each item separately (drafting, critical spirit, problemsolving, teamwork, and supervision/direction of others), except for the use of new technologies. The GHQ12 and AES scores were negatively linked $(r-0.42$, $p<0.001$ ); see Table 3 .

Relations between psychological Whoqol-bref items and GHQ-12 items show that only 3/6 Whoqol-bref psychological items (ability to concentrate; satisfaction with self; negative feelings) are correlated with 8/12 GHQ-12 items (lost much sleep, making decisions, feeling under strain, not overcoming difficulties, depressed, losing self-confidence, thinking of oneself as a worthless person and being reasonably happy); see Table 4.

The relationship between psychological Whoqolbref and self-perceived AES (regression coefficient (rc) $0.14, p=0.019)$ was positive. The same relation existed with Whoqol-bref physical (rc 0.38, $p<$ 0.001 ), social relationships (rc $0.28, p<0.001$ ) and environmental (rc 0.19, $p<0.001$ ) domains. No link was observed between GHQ-12 and AES, but there is a negative influence on the physical Whoqol-bref domain (rc $-0.10, p<0.001$ ); see Table 5 .

\section{Discussion}

Our study is about the well-being of first-year university students (in terms of the psychological quality of life domain of the Whoqol-bref and psychological suffering from the General Health Questionnaire (GHQ-12)) and its associations with academic employability skills. Our most important finding is the connection between well-being and capacities acquired at university: the better the psychological quality of life, the greater the student's generic academic skills for employability. The psychological quality of life of freshmen is associated with all competencies except the use of new technologies (drafting, critical spirit, problemsolving, teamwork, and supervision/direction of others).

The self-assessment measure of academic skills relative to employability is [32] based on the theory of self-efficacy [39]: indeed, if employability perfor- 
Table 3

Relationships between Psychological Whoqol-bref and GHQ-12, and other determinants (bivariate tests): Mean (SD) or correlation coefficients (Pearson's correlation)

\begin{tabular}{|c|c|c|c|c|}
\hline & \multicolumn{2}{|c|}{ Psychological Whoqol-bref score } & \multicolumn{2}{|c|}{ GHQ-12 score } \\
\hline & Mean (SD) & $p$-value & Mean (SD) & $p$-value \\
\hline \multicolumn{5}{|l|}{ Group } \\
\hline Sciences and Technology & $72.0(14.7)$ & 0.424 & $13.9(4.6)$ & 0.221 \\
\hline Law and Finance & $74.1(14.3)$ & & $11.7(5.0)$ & \\
\hline Social Sciences & $74.6(14.3)$ & & $12.4(3.6)$ & \\
\hline \multicolumn{5}{|l|}{ Sex } \\
\hline Female & $73.2(14.2)$ & 0.515 & $12.9(3.6)$ & 0.180 \\
\hline Male & $74.3(14.6)$ & & $11.6(5.6)$ & \\
\hline \multicolumn{5}{|l|}{ Nationality } \\
\hline Luxembourger & $73.9(14.0)$ & 0.629 & $12.2(4.3)$ & 0.583 \\
\hline Other & $73.1(15.1)$ & & $12.7(4.7)$ & \\
\hline \multicolumn{5}{|l|}{$12^{\text {th }}$ grade diploma } \\
\hline General & $73.9(14.4)$ & 0.578 & $12.2(4.1)$ & 0.631 \\
\hline Professional or technical & $72.9(14.5)$ & & $12.8(5.3)$ & \\
\hline \multicolumn{5}{|l|}{ Father's educational level } \\
\hline Under $12^{\text {th }}$ grade & $70.9(15.4)$ & 0.685 & $12.1(4.9)$ & 0.430 \\
\hline $12^{\text {th }}$ grade and above & $69.9(14.8)$ & & $12.8(3.7)$ & \\
\hline \multicolumn{5}{|l|}{ Mother's educational level } \\
\hline Under $12^{\text {th }}$ grade & $73.9(14.1)$ & 0.423 & $12.7(4.9)$ & 0.281 \\
\hline $12^{\text {th }}$ grade and above & $72.5(15.1)$ & & $11.7(4.2)$ & \\
\hline \multicolumn{5}{|l|}{ Father's professional status } \\
\hline Manual worker & $74.0(13.6)$ & 0.331 & $12.6(4.6)$ & 0.573 \\
\hline Senior officer & $72.3(15.7)$ & 7 & $12.0(4.2)$ & \\
\hline \multicolumn{5}{|l|}{ Mother's professional status } \\
\hline Manual worker & $73.8(14.2)$ & 0.453 & $12.4(4.5)$ & 0.764 \\
\hline Senior officer & $72.2(15.1)$ & & $12.1(4.5)$ & \\
\hline Age (year) & 0.00 & 0.944 & 0.13 & 0.217 \\
\hline GHQ-12 & -0.42 & $<0.001^{* * *}$ & - & - \\
\hline Psychological Whoqol-bref domain & & - & -0.42 & $<0.001^{* * *}$ \\
\hline Physical Whoqol-bref domain & 0.64 & $<0.001^{* * *}$ & -0.36 & $<0.001^{* * *}$ \\
\hline Social relationships Whoqol-bref domain & 0.51 & $<0.001^{* * *}$ & -0.20 & $0.050^{*}$ \\
\hline Environmental Whoqol-bref domain & 0.51 & $<0.001^{* * *}$ & -0.26 & $0.012^{*}$ \\
\hline Satisfaction with university services & 0.17 & 0.109 & -0.15 & 0.160 \\
\hline Academic Employability skills (AES) score & 0.25 & $<0.001 * * *$ & -0.03 & 0.795 \\
\hline AES item 1 - Drafting/writing & 0.18 & $0.002 * *$ & -0.01 & 0.945 \\
\hline AES 2 - Critical spirit/having sound judgment & 0.17 & $0.003^{* *}$ & 0.04 & 0.705 \\
\hline AES 3 - Problem solving & 0.23 & $0.000^{* * *}$ & -0.12 & 0.232 \\
\hline AES 4 - Teamworking & 0.16 & $0.004^{* *}$ & 0.03 & 0.778 \\
\hline AES 5 - Supervision/direction of others & 0.25 & $0.000 * * *$ & -0.07 & 0.510 \\
\hline AES 6-Use of new technologies & 0.10 & 0.074 & -0.01 & 0.931 \\
\hline
\end{tabular}

${ }^{*} p<0.05,{ }^{* *} p<0.01,{ }^{* * *} p<0.001$.

mance depends on the knowledge, skills and abilities possessed, how to use those assets and present them to employers depends on confidence in one's own value. We observed that the academic employability skills profile is coherent with the courses followed: for example, Social Sciences students mainly declared capacities for drafting/writing, (critical judgment, NOT CLEAR) and teamworking, and students of Sciences and Technology highlighted their performance in solving problems and using new technologies. Recent studies show that the health behaviour of first-year university students differs from that of their working peers.
Drinking and drink-related problems increased during the study and are much more prevalent among students than others in the same age group. Moreover, this health behaviour affects their quality of life assessment, which is not the case among their working peers [15]. In addition, employed young people scored higher in their self-perceived quality of life than did students [40].

The psychological quality of life from the Whoqolbref and the psychological suffering from the General Health Questionnaire (GHQ-12) scores differ greatly between countries (see Table 6). In Luxembourg, the 


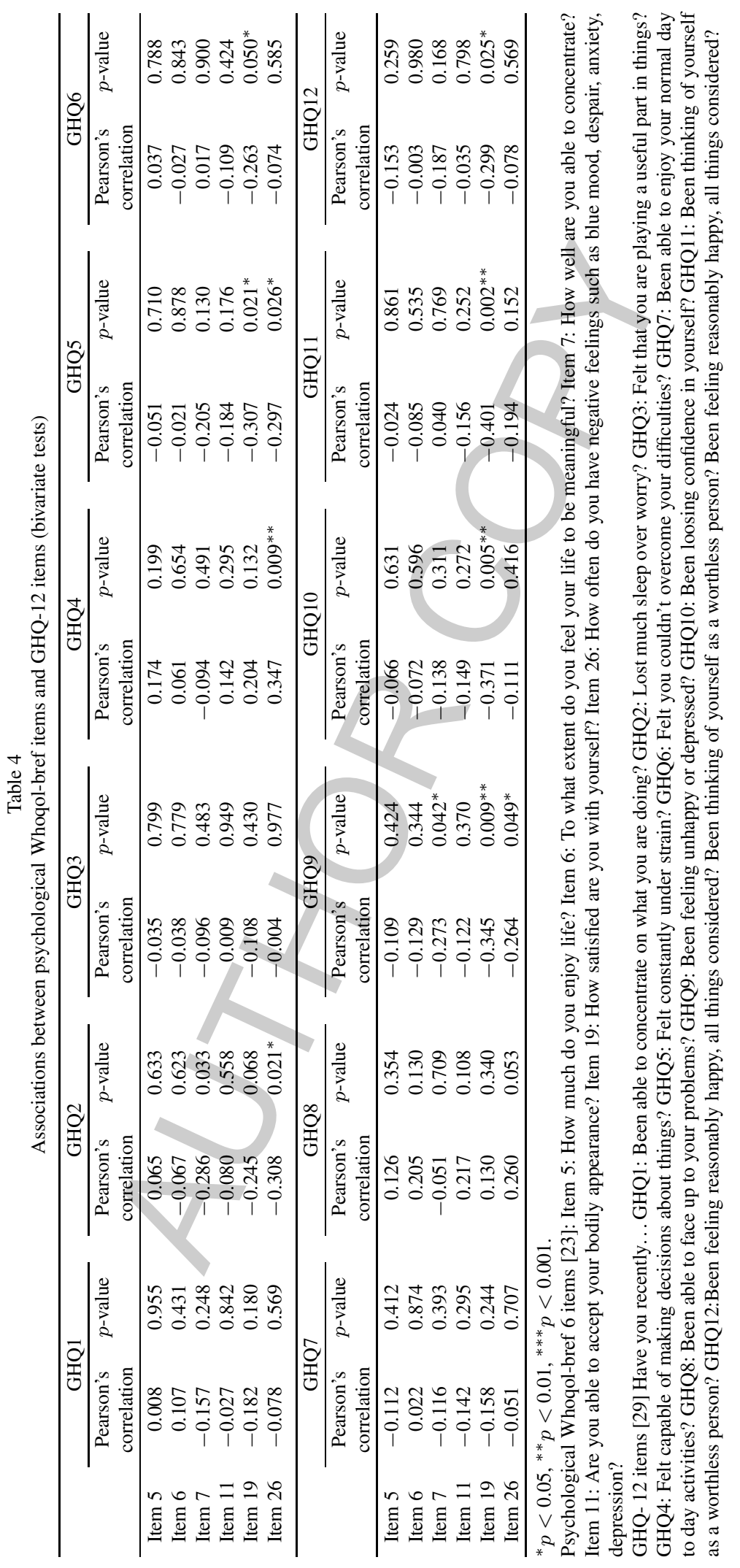


Table 5

Effects of self-perceived Academic Employability Skills and other determinants on psychological Whoqol-bref and GHQ-12. regression coefficient (SE) and $95 \%$ confidence interval

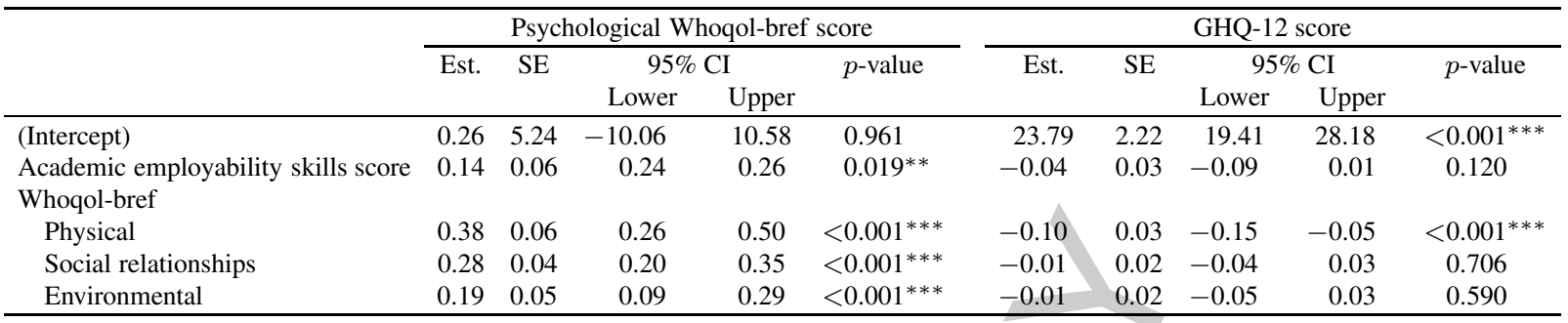

${ }^{*} p<0.05,{ }^{* *} p<0.01,{ }^{* * *} p<0.001$.

Table 6

Psychological Whoqol-bref and General Health Questionnaire (GHQ-12) scores among students: results from the literature: Mean (SD = standard deviation)

\begin{tabular}{llrrr}
\hline Authors & Country & $N$ & Age (SD) & Psychological Whoqol-bref [0-100] \\
\hline Eurich 2008 [25] & Brazil & 67 & $21.2 \pm 4.3$ & $69.3(12.3)$ \\
Hassed 2009 [26] & Australia & 148 & $18.8 \pm 1.1$ & $65.6(16.1)$ \\
Kaliseti 2004 [27] & Turkey & 150 & 19 & $60.7(14.7)$ \\
Li 2009 [51] & Thailand & 407 & $20.5 \pm 1.2$ & $68.1(11.0)$ \\
Wu 2007 [52] & Taiwan & 304 & $20.1 \pm 1.7$ & $54.4(12.0)$ \\
Sciences Technology Law and & Luxembourg & 93 & $20.8(4.3)$ & $72.0(14.7)$ \\
Finance Social Sciences & Our present survey & 126 & $20.9(3.5)$ & $74.1(14.3)$ \\
& & 102 & $21.4(4.2)$ & $74.6(14.3)$ \\
\hline Authors & Country & $N$ & Age (SD) & GHQ-12 score [0-36] \\
\hline Özdemir 2000 [8] & Turkey & 115 & $21.9 \pm 2.2$ & $7.5 \pm 3.7$ \\
Baumann 2008 [53] & France & 934 & $20.0 \pm 2.0$ & $12.8 \pm 5.4$ \\
& Poland & 479 & & $15.3 \pm 5.3$ \\
Cotton 2002 [54] & Romania & 195 & & $13.8 \pm 4.2$ \\
Roberts 2000 [7] & South Australia & 176 & $25.0 \pm 9.0$ & $15.9 \pm 7.3$ \\
Sciences Technology Law and & United Kingdom & 468 & $23.4 \pm 4.8$ & $13.5 \pm 6.5$ \\
Finance Social Sciences & Luxembourg & 93 & $20.8(4.3)$ & $13.9(4.6)$ \\
& Our present survey & 126 & $20.9(3.5)$ & $11.7(5.0)$ \\
& & 102 & $21.4(4.2)$ & $12.4(3.6)$ \\
\hline
\end{tabular}

students' psychological quality of life was higher than, or similar to, that reported in other studies among university students. Social Sciences students had a higher psychological quality of life than did their counterparts in Brazil [25]. Regarding the mental distress scored by the GHQ12, the Law and Economics students achieved values lower only in Turkey [8]. These results may be considered as satisfactory in the European context, given continuous changes in the demographic pattern of the student body, and difficult global economic circumstances.

The following hypotheses may be raised:

(1) Better psychological quality of life is associated with acquisition of skills that increase employability among the group in which female students were most represented, namely those studying Social Sciences.

(2) The Social Sciences group included the highest proportion of Luxembourg natives, and the high- est level of self-perceived employability skills. Our hypothesis is that a number of students already possess high individual capacities. For them, the competencies relative to employability to ensure their professional future have been insufficient. Their need is not met by the various seminars and courses, creating dissatisfaction which probably affected their psychological quality of life.

(3) The difference between faculties could be attributable to the academic employability skills taught in each school: self-assessed capacities like drafting/writing, critical judgment and team working that Social Sciences students mainly declared may be more complex to learn.

Our findings confirm that individual health, health behaviour, health complaints, and financial parameters are selectively associated with some but not all indicators of student educational achievement [9]. 
As in a previous study, no gender difference or other determinant which produces social inequality was observed despite being recognized in the literature as resulting in morbidity [41]. In the same way, no association exists between psychological quality of life or academic employability skills and students' satisfaction with the university services; a factor reported to be a determinant of academic success and educational achievement [42].

The study focused on both psychological suffering and quality of life, but only one facet of well-being appears related to academic skills towards employability. Indeed, when we analysed the content of the items (Table 4), for example, ability to concentrate, self-satisfaction and negative feelings, we remark that they are associated with factors such as being anxious, unable to concentrate on a task or be happy with oneself, which can be considered as psychological reflections of quality of life. In contrast, the body image, the meaning that we give to life or enjoyment of life are strongly influenced by the social environment, (e.g. the people with whom one lives, to whom one speaks and whose opinion matters). Students spend much time at university, they meet other young people, lecturers, and academic staff who set the standards by which they are compared and from which they assess their satisfaction with the quality of their life and their environmental conditions.

Due to the emphasis on employability in higher education, the mastery of AES should imply better academic adjustment of the first year students. GHQ12 measures psychological suffering and its health related-outcomes, so a high level of psychological suffering contributes to a decrease in physical quality of life. Although the cross-sectional study design precludes conclusions about the direction of the link, a recent survey confirmed that the prevalence of psychiatric disorders among first-year students is correlated with increased difficulty in adapting to university education [43]. Our study shows that the psychological Whoqol-bref score is an interesting indicator to include in the monitoring of students' well-being; it could be used to evaluate the influence on relevant educational achievement predictors of programmes and services of a comprehensive health promotion plan. Indeed, students who leave university without having obtained a diploma represent an important economic, psychological and social cost for the students themselves and wider society. Student dropout is affected by multiple factors; nevertheless, with the mobility developed by the European Higher Educational Area and the
Bologna Process, the university environment undoubtedly plays an important part [44]. So, psychological quality of life from the Whoqol-bref and psychological suffering from the GHQ-12 are both useful instruments with which to explore well-being at university. They complement each other: psychological suffering from the GHQ-12 provides important data to prevent mental troubles of the most vulnerable students, and psychological quality of life from the Whoqol-bref facilitates provision of an environment conductive to learning.

\section{Limitations}

First, the survey was conducted among volunteers in their first year of higher education and the results cannot be generalized. Although the population is small, the participation rate $(33 \%)$ is in accord with the literature $(27 \%)$ including a web-based survey [45]. Second, the voluntary completion of the web-based selfadministered questionnaire might lead to bias in terms of participation and responses to questions [46]. However, the web-format Whoqol-bref is considered equivalent to the paper version [45], and the quality of the completed questionnaires was very high. Third, the predominance of female students in our sample is consistent with similar observations have been made elsewhere [12]. Women are more motivated to participate in investigations and to provide information on their well-being. At the opposite, the men are recognized to be low responders to surveys anyway $[47,48]$.

\section{Conclusion}

Our study shows it is important to assess indicators of well-being and to create benchmarks to monitor students during their first university year. We also need to better understand the relationship between well-being and the acquisition of employability skills, how they are constructed and how they operate in a globalized academic market. Such tracking allows the provision of appropriate assistance and services [4], optimisation of coaching, and the development of a dynamic view of employability that allows for ongoing training opportunities.

In this context, many universities have created tutoring groups to help students manage their university work and develop [successful working methods [49]. Moreover, specific disciplines such as Social Sciences can promote 'help workshops' that aim to improve ac- 
quisition of skills like drafting/writing, critical thinking, problem-solving, teamwork, supervision, and use of new technology. Information also plays an important role in the promotion of autonomy, self-respect and development of the ability to take action. It increases the participation of students in their training and improves their performance [50].

Creating working groups specifically to connect students with potential employers, arranging meetings with professionals and sessions on job-seeking techniques also help students gain confidence in their capabilities and, according to our results, to increase their well-being. Participation in these activities promotes peer interaction and contributes to student support. Our findings are essential to those designing and implementing individual or community programs in health promotion because they lead to a consideration of other types of support: workshops to develop empowerment strategies, discussion groups, welfare initiatives, individual help, information provided on websites, leaflets and hotlines, and other means to increase the capacity of students to cope with anxiety and manage their lives.

\section{Acknowledgments}

Thanks to: All the volunteer students of the University of Luxembourg, without whom this research could not have been undertaken. This project 2008-2010 was supported by a financial grant from the University of Luxembourg.

\section{References}

[1] Roberts R, Golding J, Towell T, Weinreb I. The effects of economic circumstances on British students' mental and physical health. J Am Coll Health. 1999; 48: 103-109.

[2] Verger P, Guagliardo V, Gilbert F, Rouillon F, Kovess-Masfety V. Psychiatric disorders in students in six French universities: 12-month prevalence, comorbidity, impairment and helpseeking. Soc Psychiat Psychiatric Epidem. 2010; 45: 189-199.

[3] Eisenberg D, Golberstein E, Gollust SE. Help-seeking and access to mental health care in a university student population. Med Care. 2007; 45: 594-601.

[4] Stecker T. Well-being in an academic environment. Med Educ. 2004; 38: 465-478.

[5] Limbach-Reich A. Students with disabilities in a crossnational context. Studiowanie $\mathrm{z}$ niepełnosprawnośią Najnowsze badanie na temat sytuacji w Wielkim Regionie, pięć lat po utworzeniu Konwencji Praw Osób z Niepełnosprawnościami ONZ. Poland, Warsaw, June 29-July 1, book of the $3^{\text {rd }}$ International Conference of Education. 2011: 56.

[6] Chau K, Baumann M, Kabuth B, Chau N. School difficulties and role of social, material, behavioural, physical and mental resources among multi-cultural students. BMC Public Health 2012; 12: 453-464.
[7] Roberts S, Golding J, Towell T, Reid S, Woodford S. Mental and physical health in students: the role of economic circumstances. Brit J Health Psychol. 2000; 5(3): 289-297.

[8] Özdemir U, Tuncay T. Correlates of loneliness among university students. Child Adol Psych Ment Health. 2000; 2: 29-39.

[9] El Ansari W, Stock C. Is the Health and Well-being of University Students Associated with their Academic Performance? Cross Sectional Findings from the United Kingdom. Int J Environ Res Public Health. 2010; 7: 509-527.

[10] Baumann M, Spitz E, Guillemin F, Ravaud JF, Choquet M, Falissard B, Chau N. Associations of social and material deprivation with tobacco, alcohol, and psychotropic drug use, and gender differentials. Int J Health Geographic. 2007; 2: 5060.

[11] Boujut E, Koleck M, Bruchon-Schweitzer M, Bourgeois ML. Mental health among students: A study among a cohort of Frenchmen. Annales Medico-Psychologiques. 2009; 167(9): 662-668.

[12] Craig TKJ. Students' Health Needs: Problems and Responses. The Psychiatrist. 2004: 28, 69-70.

[13] Vilhjalmsdottir G. Occupational Thinking and Its Relation to School Dropout. J Career Develop. 2010; 37(4): 677-691.

[14] Ross CE, Wu C. Education, Age, and the Cumulative Advantage in Health. J Health Soc Behavior. 1996; 37(1): 104-120.

[15] Vaez M, Ekberg K, Laflamme L. Ratings of health and quality of life by young working people: Are there occupational or education-based differences? Work. 2004; 23(3): 193-198.

[16] Amara ME, Baumann M. L'Europe Universitaire. L'identité d'étudiante face à l'employabilité. Belgique, Louvain la Neuve: Ed. Academia L'Harmattan, coll. INSIDE; 2012.

[17] Hillage J, Pollard E. Employability: Developing a framework for policy analysis. UK, London: Department for Education and Employment, n RR85, 1998.

[18] Glover D, Law S, Youngman A. Graduations and Employability: Student perceptions of the personal outcomes of university education. Res Post-Compulsory Educ. 2002; 7(3): 293306.

[19] Jameson J, Strudwick K, Bond-Taylor S, Jones M. Academic principles versus employability pressures: A modern power struggle or a creative opportunity? Teach High Educ. 2012; 17(1): 25-37.

[20] European Council. The Bologna Process 2020 - Towards the european higher education area. Louvain-La-Neuve, Belgium; 2009. [http://ec.europa.eu/education/higher- education/ doc1290_en.htm].

[21] Moir J. Students, knowledge and employability. World Academy of Science. Engineering Technol. 2012; 64, 166170.

[22] Musschenga AW. The relation between concepts of qualityof-life, health and happiness. J Med Philosophy. 1997; 22(1): 11-28.

[23] Skevington SM, Lotfy M, O' Connell KA. The World Health Organization's WHOQOL-BREF quality of life assessment: psychometric properties and results of the international field trial. A report from the WHOQOL group. Qual Life Res. 2004; 13: 299-310.

[24] Saupe RS, Nietche EA, Cestari ME, Giorgi MD, Krahl M. Quality of life of nursing students. Rev Latino-Americano Enfermagem. 2004; 12 (4): 636-642.

[25] Eurich RB, Kluthcovsky AGC. Evaluation of quality of life of undergraduate nursing students from first and fourth years: the influence of sociodemographic variables. Rev Psiquatria do Rio Grande do Sul. 2008; 30(3): 211-220.

[26] Hassed C, de Lisle S, Sullivan G, Pier C. Enhancing the health 
of medical students: outcomes of an integrated mindfulness and lifestyle program. Adv Health Sci Educ. 2009; 14(3): 387398.

[27] Kalitesi Y, Destek S, Yalnizlik S, Iliskiler A. Relationships between quality of life, perceived social support, social network, and loneliness in a Turkish sample. Yeni Symposium. 2004; 42(1): 20-27.

[28] Hoeymans N, Garssen AA, Westert GP, Verhaak PF. Measuring mental health of the Dutch population: a comparison of the GHQ-12 and the MHI-5. Health Qual Life Outcomes. 2004; 2: 23-28.

[29] Goldberg DP, Gater R, Sartorius N, Ustun TB, Piccinelli M, Gureje O, Rutter C. The validity of two versions of the GHQ in the WHO study of mental illness in general health care. Psychol Med. 1997; 27(1): 191-197. [www.eurofound. europa.eu/publications/focusform.htm: How are you?].

[30] Bella TT, Omigbodun OO. Social phobia in Nigerian university students: prevalence, correlates and co-morbidity. Soc Psych Psychiat Epidem. 2009; 44(6): 458-463.

[31] Gorter R, Freeman R, Hammen S, Murtomaa H, Blinkhorn A, Humphris G. Psychological stress and health in undergraduate dental students: fifth year

[32] Rotwell A, Jewell S, Hardie M. Self-perceived employability: investigating the reponses of post-graduate students. J Vocat Behavior. 2009; 75: 152-161.

[33] Angermeyer MC, Kilian R, Matschinger H. WHOQOL 100 und WHOQOL BREF. Handbuch für die Deuschprachige Version der WHO Instrumente zur Erfassung von Lebensqualität: Ed. Hogrefe, Deutschland, Göttingen; 2000.

[34] Leplège $\mathrm{A}$, Réveillère $\mathrm{C}$, Ecosse $\mathrm{E}$, Caria $\mathrm{A}$, Rivière $\mathrm{H}$. Propriétés psychométriques d'un nouvel instrument d'évaluation de la qualité de vie, le WHOQOL-26, à partir d'une population de malades neuromusculaires. Encéphale. 2000; 26: 1322.

[35] Goldberg DP, Gater R, Sartorius N, Ustun TB, Piccinelli M, Gureje O, Rutter C. The validity of two versions of the GHQ in the WHO study of mental illness in general health care. Psychol Med. 1997; 27(1): 191-197.

[36] Schmitz N, Kruse J, Tress W. Psychometric properties of the General Health Questionnaire (GHQ-12) in a German primary care. Act Psychiat Scand. 1999; 100(6): 462-468.

[37] Salama-Younes M, Montazeri A, Ismaïl A, Roncin C. Factor structure and internal consistency of the 12-item General Health Questionnaire (GHQ-12) and the Subjective Vitality Scale (VS), and the relationship between them: a study from France. Health Qual Life Outcomes. 2009; 7: 22-28.

[38] Lin Z, Sweet R, Anisef P, Schuetze H. Consequences and policy implications for university students who have chosen liberal or vocational education. Labour market outcomes and employability skills. Human Resources Development, Canada; 2000. [http://www.rhdsc.gc.ca/fr/sm/ps/rhdc/rpc/ publications/recherche/2000-000184/page00.shtml].

[39] Bandura A. Auto-efficacité. Le sentiment d'efficacité personnelle (J. Lecomte, Trans.). Ed. De Boeck: Belgique, Bruxelles; 2003.
[40] Hultman B, Hemlin S. Self-rated quality of life among the young unemployed and the young in work in northern Sweden. Work. 2008; 30: 461-72.

[41] Baumann M, Aïach P. [Promotion of health and reduction of the social inequalities of health in Europe]. In: Aïach P. (dir.) Social inequalities of health. Economica ed. Anthropos, coll. Sociological, Paris, France, 2010; 245-262.

[42] Wardle J, Steptoe A, Gulis G, Sartory G, Sek H, Todorova I, Vogele C, Ziarko M. Depression, perceived control, and life satisfaction in university students from Central-Eastern and Western Europe. Int J Behav Med. 2004; 11(1): 27-36.

[43] Patel V, Flisher AJ, Hetrick S, McGorry P. Mental health of young people: a global public-health challenge. Lancet. 2007; 369: 1302-1313.

[44] Christie H, Munro M, Fisher T. Leaving university early: exploring the differences between continuing and noncontinuing students. Stud Higher Educ. 2004; 29(5): 617-636.

[45] Chen WC, Wang JD, Hwang JS, Chen CC, Wu CH, Yao G. Can the Web-Form WHOQOL-BREF be an alternative to the Paper-Form? Soc Indic Res. 2009; 94(1): 97-114.

[46] Brener ND, Kann L, Kinchen SA, Grunbaum JA, Whalen L, Eaton D, Hawkins J, Ross JG. Methodology of the youth risk behavior surveillance system. MMWR Recomm Report. 2004; 24, 53(RR-12): 1-13.

[47] Dunn KM, Jordan K, Lacey RJ, Shapley M, Jinks C. Patterns of consent in epidemiologic research: evidence from over 25,000 respondents. Am J Epidem. 2004; 159(11): 10871094.

[48] Van Loon AJM, Tijhuis M, Picavet HSJ, Surtees PG, Ormel $J$. Survey non-response in the Netherlands: Effects on prevalence estimates and associations. Ann Epidem. 2003; 13: 105110.

[49] Monaghan D, Chaloux N. Evaluation d'un programme d'aide à la réussite. CEGEP de Sainte-Foy: Ed. Québec, Canada; 2004.

[50] Spitz E, Costantini ML, Baumann M. [Adaptation and strategies of coping of the students in first academic year]. Rev Francophone Stress Trauma. 2007; 7(3): 217-225.

[51] Li K, Kay NS, Nokkaew N. The performance of the World Health Organization's WHOQOL-BREF in assessing the quality of life of Thai college students. Soc Indic Res. 2009; 90(3): 489-501.

[52] Wu CH, Yao G. Examining the Relationship between global and domain measures of quality of life by three factor structure models. Soc Indic Res. 2007; 84(2): 189-202.

[53] Baumann M, Spitz E, Chau N, Ionescu I, Bucki B, Constantini ML, Le Bihan E. Impact of perceived financial situation and stress coping strategies on mental distress among French, Romanian and Polish students. 12th International Congress of the European Society for Health and Medical Sociology, Oslo, Norway, 27-29 August. Congressbook ESHMS, 2008: 14.

[54] Cotton SJ, Dollard MF, de Jonge J. Stress and student job design: Satisfaction, wellbeing, and performance in university students. Int J Stress Manag. 2002; 9(3): 147-162. 